МАРІЯ ЯКУБОВСБКА, кандидат філологічних наук, дочент кафедри інформачійної, бібліотечної та книжкової справи, Українська академія друкарства, Украӥна

ORCID 0000-0002-7774-955x mmamariat92@gmail.com

ВАЛЕНТИНА ДАНЬШОВА, викладач-методист вищої категорії, ДВНЗ "Київький механіко-технологічний коледж", Україна ORCID 0000-0003-3807-3400

ШУЦЬКИЙ БРОНІСЛАВ, народний артист Украӥни, конџертмейстер групи альтів симфонічного оркестру Національного академічного театру опери та балету України імені Тараса Шевченка, викладач начіональної музичної академії України імені Петра Чайковського ORCID 0000-0002-5645-6467 shchutzkiy@ukr.net

\title{
КУЛЬТУРОЛОГІЧНА ПАРАДИГМА СУЧАСНОСТІ - ОСНОВА ФОРМУВАННЯ КУЛЬТУРИ ОСОБИСТОСТІ
}

MARIA YAKUBOVSKA, Candidate of Philological Sciences, associate Professor of the Department of Information, Library and Book Affairs Ukrainian Academy of Printing, Lviv, Ukraine

VALENTINA DANSHOVA, teacher-methodologist of the highest category of the State Higher Educational Institution "Kyiv Mechanical and Technological College", Ukraine

SHCHUTSKY BRONISLAV, National Artist of Ukraine, a concertmaster of the alto singers of the Symphony Orchestra of Taras Shevchenko National Opera and Ballet Theatre of Ukraine, a teacher of Petro Tchaikovsky National Music Academy of Ukraine

\section{THE CULTURAL PARADIGM OF MODERNITY - BASIC FORMATION OF PERSONAL CULTURE}

У статті порушено проблеми науково-теоретичних аспектів алгоритму інноваційних змін у системі вищої школи, в основі яких відповідь сучасної педагогічної науки на виклики новітньої доби, коли педагогіка, виконуючи свої історичні завдання, створює передумови для утвердження якісних інноваційних процесів педагогічної взаємодії у системі "викладач студент", що становить основи гуманітарної безпеки нашого суспільства. Нами окреслені системні процеси, у яких закладені формування культурологічної компетентності студентів, системне еволюційне осмислення дискурсу сучасної освіти та забезпечення варіативних технологій культурологічної освіти.

Ключові слова: культурологічна компетентність, культурологічний світогляд, дискурс, психолог-

\footnotetext{
(C) М. Якубовська, В. Даньшова, Б. Шуцький
}

ічна безпека суспільства, культурологічна свідомість, мистецтво спілкування, культурологічне середовище, психологічний захист особистості.

Summary. The article deals with the problems of theoretical and theoretical aspects of the algorithm of innovative changes in the system of higher education, the basis of which is the response of modern pedagogical science to the challenges of the modern era, when pedagogy, fulfilling its historical tasks, creates the prerequisites for the establishment of qualitative innovative processes of pedagogical interaction in the system "teacher student ", which forms the basis of the humanitarian security of our society. The article outlines the algorithm of system processes, in which the formation of students 'cultural competence, system evolutionary comprehension of the discourse of modern education and the provision of variational technologies of students' cultural education are formed on the basis of the discourse of the interaction of scientific and artistic thinking as the basis of cultural communication; Partial analysis of the trends of personal and humanitarian technology teaching cultural studies in higher education institutions; Partial analysis of the system of culturological space in the algorithm of man-centered model of modern education.

Key words: culturological competence, cultural worldview, discourse, psychological safety of society, cultural consciousness, art of communication, culturological environment, psychological protection of personality.

Мета: розглянути проблеми формування культурологічного мислення на основі інноваційних процесів у системі закладів вищої освіти технічного профілю як предмет цілісного та системного дослі- 
дження, що складає основу гуманітарної безпеки суспільства; дослідити культурологічні процеси, які відбуваються у молодіжному середовищі; показати вплив предметів гуманітарного циклу на формування культурологічного світогляду молодої людини, тенденції співпраці технічного та гуманітарної складових педагогічно зорієнтованої педагогіки сучасності.

Постановка проблеми в загальному вигляді. Для успішної підготовки кадрів у системі закладів вищої освіти важливим є формування культурологічної компетентності студентів, яке складає основу гуманітарної безпеки сучасності. Важливим у даних процесах $\epsilon$ дослідження науково-теоретичних аспектів формування алгоритму інноваційних змін у системі закладів вищої освіти. Актуальним вважаємо також і дослідження вироблення взаємозв'язку системи формування культурологічної та професійної компетентності студентів. Проте вивчення формування культурологічної компетентності студентів на основі інноваційних процесів у системі культурологічного простору сучасності ще не стало об'єктом концептуального наукового висліду.

Аналіз досліджень і публікацій. Про актуальність даної теми свідчить те, що в нинішній час існує ряд праць, що стосуються формування культурологічного світогляду студентів. Зокрема, формування культурологічної компетентності як інноваційної парадигми сучасності досліджують В. Андрущенко, В. Кремінь, С. Гончаренко, I. Зязюн, Н. Ничкало, В. Огнев'юк, Т. Герлянд, Л. Герганов, М.Свтух, Л. Єршова, А. Каленський, П. Лузан, М. Пантюк, Л. Пригодій, В.Орлов, I. Пасічник, Л. Пуховська, В.Радкевич, Л. Романишина, С. Сисоєва, М. Теловата, О. Щербак, В.Ягупов та інші.

Гончаренко наголошує: "Культура - сукупність практичних, матеріальних і духовних надбань суспільства, які відображають історично досягнутий рівень розвитку суспільства й людини і втілюються в результатах продуктивної діяльності" (Мистеитво.., 2006, с. 182).

Питання культурологічної підготовки студентів, що розгляда- ються у сучасній педагогічній науці, класифіковано за такими напрямами: визначальна роль вищої професійної освіти у стратегії духовно-екзистенційної боротьби за оновлення суспільства (В.Кремінь, I. Зязюн, Н. Скотна, О. Вишневський, І. Пасічник, О. Невмержицька); система неперервної професійної освіти (С. Гончаренко, Н.Ничкало, В. Луговий, С. Сисоєва); організація навчального процесу у вищих навчальних закладах (С. Сисоєва, М. Чепіль, Т. Логвиненко); наукова педагогічна термінологія професійної освіти і навчання у країнах Європейського Союзу (Л.Пуховська, С. Леу, О. Радкевич, М. Шимановський, О. Бородієнко); професійний розвиток та саморозвиток студентів (В. Кремінь, О. Коваленко, Н. Скотна, М. Васильєва, Л. Лебедик, О. Овчарук, А. Кузьмінський, В. Кемінь); упровадження інноваційних технологій у системі вищої професійної школи (П.Вербицька, В. Кушнір, Т. Кристопчук, Н. Костриця, І. Пасічник, В. Свистун, В. Ягупов, М. Лук'янченко, Л. Оршанський).

Виклад основного матеріалу дослідження. Людиноцентричність як філософсько-психологічна проблема стає основою сучасних педагогічних інновацій професійної освіти. Як переконують спостереження, існує тісний діалектичний взаємозв'язок між філософськими сентенціями і становленням сучасної педагогічної науки.

Бех І. Д. накреслив алгоритм формування духовно-екзистенційних основ особистості у системному відтворенні "від культури мислення до культури духовного переживання". У статті "Духовна особистість у контексті освітніх викликів" видатний учений Бех I. Д. наголошує: "Багатовікове відчуження людини від справжніх духовних цінностей призвело до кризових явищ, пов'язаних із занепадом духовно-моральних ідеалів, посиленням зла і насильства. Девальвація духовних цінностей суттєво вплинула на посилення тенденції зростання жорстокого індивідуалізму, прагматизму, зверхнього ставлення до інших людей та приниження їхньої гідності, зневаги до рідної культури та історико-культурних традицій" (Держ. стандарти.., 2002, с. 3).
На рубежі епох, тисячоліть, століть, коли посилюються деструктивні елементи в суспільному поступі, людство, шукаючи вихід із загальної кризи, яка охопила всі сфери буття, укотре звертається до педагогіки як духовно-синенергетичної підвалини найрізноманітніших форм сучасного буття людини та суспільства. Як справедливо наголошує В.Кремінь: "Шлях України - це не псевдодемократія і не тоталітарна диктатура, а демократичний і водночас національний тип державності, що є найближчим до корпоративної демократії і корпоративної державності. Цей тип і є шляхом до сучасної української державності, сильної державної влади, яка діє винятково в рамках права і саме в рамках правової держави знаходить оптимальний баланс між ідеєю свободи й ідеєю справедливості" (Ничкало, 2013, с. 307).

Система структурної аксіологічної парадигми вимагає творення культурологічних орієнтирів у кожну окремо визначену епоху. $\mathcal{E}$ системні цінності, які залишаються актуальними на багато століть, а $є$ такі, що набувають найбільшої актуальності в певний період.

Аксіологічна складова виступає важливим чинником у формуванні сучасної особистісно орієнтованої парадигми професійної освіти. Творення культурологічної парадигми відбувається за рахунок конкретної фактологічної бази, методів і способів зіставлень, аналітичності висновків тощо.

Відображення культурологічного поступу соціуму формується у системних аналізах за допомогою переконань. Завдання культурологів сучасності полягає у побудові наскрізної лінії культурологічного творення парадигми сучасності.

Г. Ващенко у праці "Хвороба в галузі національної пам'яті" наголошує: "Особливо потрібна творча уява українській молоді. Історія поставила перед нею складні й трудні завдання: вибороти волю для своєї Батьківщини, піднести їі зі стану руїни, розбудувати її культуру й цивілізацію, поставити їі в ряд передових держав світу. Для цього потрібна нашій молоді тверда непохитна воля, знання, технічна озброєність і міцна творча уява" (Мистецтвво.., 2006, с. 52). 
Є вічні цінності, які залишаються актуальними в будь-який період життя людини, - добро, милосердя, активність, творчість, взаємодопомога. Але на певному історичному шляху розвитку окремі риси набувають особливої актуальності. Відображення як необхідна складова кінцевої мети діяльності полягає у досягненні впливу, у якому і трансформуються інформаційна, пізнавальна функції, які не можуть реалізуватися поза методом переконання.

Сучасна культурологія, користуючись засобами логічних переконань, використовує в системі своїх інноваційних пошуків найважливіші факти історичного поступу, які стали знаковими в розвитку людства.

Спробуємо розглянути традицію творення першого підручника на прикладі творчої професійної діяльності Івана Федоровича. Особливості творення сучасної культурологічної парадигми сучасності розглядаються шляхом аналізу концептуальних засад інноваційно-педагогічної діяльності Тараса Шевченка, Андрея Шептицького, творчих дидактичних діалогів видатних діячів Ярослава Дашкевича й Ірини Калинець, Йосипа Сліпого і Володимира Ковалика. Архетип родинного вихавання знаходимо в системі культурологічної діяльності Лесі Вацеби-Матешук (доньки) та Ірини Матешук (матері).

Наша історія багата на приклади шляхетної поведінки, одержимої праці багатьох світочів українського поступу, що є важливим джерелом як формування змісту сучасної освіти, так і матеріалом для формування унікальних педагогічних технологій.

Спосіб мислительної діяльності становить основу творення культурологічної парадигми сучасності. У науково-практичній діяльності культуролог вивчає шляхи вивчення й упровадження духовних цінностей.

У вертикальному зрізі буття минуле, майбутнє й сучасне ідуть обіруч, оскільки своїми вчинками й думками у сьогоденні ми моделюємо майбутнє. Такий причинно-наслідковий зв'язок вивчається у різноплановому часово-просторовому вимірі. Письменник, починаючи $з$ давнини, створює духов- ний образ людства. Загальні закони цивілізаційного розвитку підпорядковують собі як розвиток особистості, так і розвиток держави, нації. Таким чином, філософія буття постає філософією світу, а пошук гармонії буття - синонімом краси людської індивідуальності.

Час в оновленому культурологічному просторі виступає не застиглою субстанцією. Він нашаровується етичними й естетичними пластами, а відтак є можливим повернення 3 минулого в майбутнє та навпаки. Одночасна особистісна присутність, коли думка має матеріальну силу, відображується в системному вимірі дійсності, буття та діяння. У системі професійної освіти аксіологічна складова духовної свідомості є важливим чинником формування культурологічної компетентності студентів, оскільки цінності, норми й ідеали служать духовним підгрунтям мотивації навчальної та професійної діяльності.

Крім того, аксіологічний рівень культури виступає запорукою формування індивідуального, всезагального та гармонійного становлення особистості.

Нормативно-оцінна система інноваційних тенденцій сучасної професійної освіти $є$ вагомим підгрунтям формування культурних традицій, цілісність яких зумовлює єдність історичної традиції та актуального творення парадигми модерних інноваційних навчальних систем. У випадку порушення гармонії у формуванні архетипу сучасних інновацій педагогічної освіти сьогодні унеможливлюється досягнення високих рівнів не лише культурологічної, але і професійної компетенції студентів. Відтак на перший план виходять суб'єктивні й випадкові причини, полярні ціннісні характеристики різних соціальних систем тощо. Отже, слід мати на увазі, що аксіологічні системи в парадигмі сучасної професійної освіти повинні виступати структурованими мотиваційними чинниками у формуванні культурологічної компетентності сучасного студентства.

Через систему освіти формується нова національна еліта, яка в культурологічному просторі навчального закладу засвоює норми, правила й культурологічні цінності суспільства.
Попри той факт, що впродовж останніх десятиліть у розвитку культурологічної сфери помітні тенденції практичної відсутності формування у людей почуття доброти, милосердя, співчуття, порозуміння, взаємодопомоги, а засоби масової інформації переповнені пропагандою насильства, жорстокості, пожадливого визиску, усе ж таки за допомогою культурологічної складової у процесах модернізації сучасної освіти створюється відповідне середовище, де формується культурологічна мета в дії, відбувається її відображення в динамічному процесі, в алгоритмі реалізації. Як справедливо стверджують С. Котляр, Д. Григорук у статті: "Творчі індустрії: стратегія інноваційного розвитку": "Глобалізація сьогодні - це не тільки жорстка конкуренція. Вона також впливає на людський капітал... Техногенна цивілізація та швидка зміна інформаційних технологій примушують заклади культури діяти неординарно в трьох актуальних сферах: технології, персонал та організаційні аспекти бізнесу" (Радкевич, 1999, с.101).

Мистецька творчість, а найчастіше дане явище стосується літературної творчості, притаманне багатьом науковцям, які працюють у царині технічної сфери. Творчість $\epsilon$ виявом непересічного таланту багатьох знаних науковців. Зазвичай такі особистості досягають значних висот як у своєму професійному житті, так і у культурологічній діяльності.

Обличчя і жива легенда кожного навчального закладу - викладачі, які володіють не лише високопрофесійними знаннями, уміють донести ці знання до студентів, уміло формують в них своїх однодумців у професійній сфері, ведуть конструктивні діалоги, їхні заняття відрізняються креативністю, нестандартністю, і найголовніше, вони системою своєї багатогранної творчої діяльності створюють отой культурологічний простір, який визначальний у творенні відповідного культурологічного середовища.

Їхня мистецька, літературна творчість наповнює викладацьке дійство особливою таїною. А література як факт щільної взаємодії, взаємообумовленості сприяє формуванню культурологічної комун- 
ікації, яка складається у процесі системної навчально-виховної роботи.

Культурологія на даний час у своєму арсеналі має достатньо актів для дослідження даної проблеми як у минулому часі, так i сьогоденні. Цей процес дозволяє подивитися на людську діяльність у широкому розумінні, у системі культурологічних зв'язків, які необхідні для наукового обГрунтування висновків.

Система квантового мислення творить нові асоціативні зв'язки на стикові традиційних наук, торуючи шлях не лише для народження нових галузей, а і для інноваційних напрямів у наукових дослідженнях сучасності. Баніт О.В. наголошує: "Сучасна наука розглядає сьогоднішній етап розвитку суспільства як перехід від індустріального до постіндустріального та інформаційного. Новий етап характеризується такими властивостями, як збільшення частки творчої та інтелектуальної праці, зростання обсягу наукового знання та інформації, які застосовуються у виробництві, а також переважанням у структурі економіки сфери послуг, науки, освіти і культури над промисловістю та сільським господарством" (Дичківська, 2004, с. 41).

Наприклад, література як різновид мистецького осягнення дійсності, яка вийшла 3 низин філософії, на нинішній час частково повертається у своє лоно, передбачаючи розвиток людства, включаючи у мисленнєву діяльність інтуїцію, прогностичне передбачення, створюючи умови для якісного оновлення системного синергетичного мислення сучасності.

Метод синенергетики, яким на даний час послуговується багато напрямів наукової діяльності, дозволяє не лише систематизувати мислення, а й включати нові моделі творення системного культурологічного коду сучасного буття, без яких не можна створити повнокровної картини світу. Людство постійно виходить за межу своїх традиційних можливостей, починаючи нові відліки часу. О. Бочарова у статті "Від полікультурного суспільства до міжкультурної освіти" акцентує на "підтримці соці-окультурних змін у колективному та індивідуальному вимірі" (Мистецтво.., 2006, с. 101).
Осмислюючи творчий і науковий доробок видатних постатей нашого часу, спробуємо потвердити, що ці нестандартні особистості якраз і є тими елементами інноваційної квантової світобудови сучасного культурологічного простору. Якщо навіть припустити, що об'єктивні параметри гносеологічної ситуації в певний період однакові для всіх напрямів наукового пізнання у системі вироблення методологічних установок, формування світогляду, то питома вага суб'єктивних чинників у культурологічних ситуаціях не підлягає сумніву.

Культурологія стає вагомою частиною наукового пізнання, яка дозволяє пояснити будь-яке наукове явище у світі багатовимірності зв'язків і водночас стати основою для творення наукової моделі у тій чи іншій галузі знань. Міра істинності наукового знання залежить від наявної гносеологічної ситуації і чіткості методологічних установок.

Система творення інноваційної культурологічної парадигми сучасності - завдання духовної культури нашої доби, яка пов'язана із системним розвитком гуманізації та гуманітаризації. Духовно-екзистенційні процеси потребують постійного вивчення, адже в системі цих зв'язків вимальовуються загальні тенденції розвитку людства.

Надзвичайно цінним і необхідним виступає вивчення культурологічної складової у системі особистісно зорієнтованої освіти сучасності. Дослідження ієрархічної насиченості й теоретичної складової культурологічної парадигми неможливе без перегляду творчості видатних науковців нашого часу, котрі поєднують у собі наукову і мистецьку складові. У системі їхньої багатогранної діяльності ми спостерігаємо, як щільно взаємодіє мистецька творчість 3 іншими формами наукового пізнання. Хоча нерідко культурології відводиться прикладний зміст. Проте, формуючи основи світогляду, система осмислення світу відіграє щораз більшу роль у формуванні комунікативної компетентності.

Дискурс взаємодії культурологічної компетенції із системою комунікацій є одним 3 найголовніших напрямів культурологічної спрямованості сучасної професійної освіти. У даний час важливим вва- жаємо вироблення наукових критеріїв творення культурологічного архетипу в сучасній професійній освіті.

Система особистісно зорієнтованої освіти, маючи людиноцентричне спрямування, потребує особливої уваги як до особистості викладача, так і до особистості вихованця, котрі зосереджують свої сили не лише на здобуванні вже існуючих і накопичених дотепер людством знань, а найбільше працюють на перспективне бачення розвитку людства, котре нерідко приховане в системі культурологічного коду сучасності. Поняття коду - спільне явище для багатьох гуманітарних наук. Це виокремлення смислового ядра, суті явища в системі багатоплощинних зв'язків, це розуміння характеристик як реального, так і ірреального пластів. У мистецтві якраз код дає можливість торкнутися зернини істини. Це внутрішня точка опори культурологічного явища, система першопоштовху, з якої можна починати осмислення того чи іншого процесу.

Система педагогічної діяльності в умовах вищої професійної освіти має творчий характер, котрий стосується як модерних прийомів організації навчально-виробничого процесу, так і встановлення нових асоціативних зв'язків у системі "викладач - студент". У даному випадку обидва суб'єкти виступають однією командою у системі пошуку істини.

Факт щільної взаємодії, взаємообумовленості науки і мистецтва незаперечний. Останнє продукує інтуїтивні спалахи і прозріння, значення яких важко переоцінити; хоча самі по собі вони не можуть замінити системи наукового пізнання світу. Тільки в діалектичній єдності наукової і мистецької пізнавальних систем визріває культурологічний простір як в умовах окремого навчального закладу, так і в сучасній інноваційній особистісно зорієнтованій освіті.

Коли проаналізуємо творчі досягнення минулого, то побачимо, що симбіоз науки, мистецтва і громадянської позиції притаманний більшості видатних особистостей історії. Михайло Ломоносов писав наукові трактати у формі віршованих текстів. Своїми поетичними одкровеннями вражав сучасників ви- 
датний Дмитро Менделеєв. Григорій Сковорода - філософ світового рівня - володів унікальними ізотерично-культурологічними знаннями. Його спосіб життя був продовженням науково-філософських поглядів, а художні твори складали культурологічну парадигму людського буття на багато століть уперед. Іван Котляревський - творець нової української літератури - у бурлескно-травестійній поемі "Енеїда" подав не просто філософію народного буття, показуючи взаємодію реального та ірреального світів у системі яскравих колоритних малюнків.

Наполегливість у виконанні поставлених завдань, дорога до успіху, яка ніколи не буває легкою, пошуки виходу із складної ситуаціїце культурологічні складові сучасної парадигми, яка стає надзвичайно актуальною в умовах особистісно зорієнтованої освіти.

Особистість визначає хід історії, долю людства і бере на себе відповідальність. Завдання сьогоднішньої освіти - виховати саме таку особистість, котра ніколи не буде боятися брати на себе відповідальність. А сміливі, як відомо 3 роману Івана Багряного "Тигролови", "мають щастя".

Образ місії людини у світі, завдань, які вона має виконати, - це малодосліджене на даний час питання, позаяк не вкладається у систему стереотипних постулатів. Воно і зараз працює на випередження часу. Кожна людина, прийшовши у цей світ, повинна виконати поставлені перед нею завдання.

Висновки та перспективи подальших досліджень. Культурологія стає вагомою частиною наукового пізнання, що дозволяє пояснити будь-яке наукове явище у світі багатовимірності зв'язків і водночас стати основою для творення наукової моделі в тій чи іншій галузі знань. Міра істинності наукового знання залежить від наявної гносеологічної ситуації і чіткості методологічних установок. Система творення інноваційної культурологічної парадигми сучасностізавдання духовної культури нашої доби, яка пов'язана з розвитком гуманізації та гуманітаризації. Духовно-екзистенційні процеси су- часності потребують постійного вивчення, адже у системі цих зв'язків накреслюються загальні тенденції поступу людства.

Актуалізація культурологічної складової у компетентнісно орієнтованій парадигмі освіти дозволить створити модель, у якій культура стане важливою складовою науково-теоретичної системи модернізації сучасної професійної освіти.

Поєднання технічної і гуманітарної складових у вищій професійній освіті - це обширна тема, яка інтегрується в основу дискурсу професійної школи і розвитку соціуму, так як у прямій залежності відбувається розвиток суспільства і розвиток вищої школи.

\section{СПИСОК ЛІТЕРАТУРИ}

Дичківська, I. М. (2004). Інноваційні педагогічні технології. Київ : Академвидав.

Ничкало, Н. (Ред). (2002). Державні стандарти професійної освіти: теорія і методика. Хмельницький : ТУП.

Ничкало, Н. Г., Філіпчук, Н. О., Чембержі, М. I., Харченко, П. В. $\&$ Ніколаї Г. Ю. (2006). Мистецтво у розвитку особистості. Чернівці : Зелена Буковина.

Кремень, В. \& Ткаченко, В. (1999). Україна. Шлях до себе. Проблеми суспільної трансформації. Київ.

Кремень, В. (2012). Духовність і культура суспільства визначаються розвитком освіти. Edukacja wspoteczens twachwielo kulturowych. Варшава.

Кремень, В. Г. Філософія національної ідеї. Людина. Освіта.

Ничкало, Н. Г. (2013). Професійне навчання дорослого населення: теоретико-методологічні засади. Київ - Кіровоград : Імекс.

Ничкало, Н. Г. (1996). Теоретико-методологічні проблеми розвитку досліджень з педагогіки і психології професійної освіти. $M a$ теріали I міжн. філ.-культ. читань. Львів.

Радкевич, В. О. (1999). Інтеграція загальнохудожньої та професійної підготовки фахівців художнього профілю. Педагогіка і психологія професійної освіти. Львів, $1,68-72$.
Радкевич, В. О. (2000). Концепція професійно-художньої освіти. Професійно-технічна освіта, 2, 43-47.

Шоробура, I. М. (2016). Історико-педагогічний вимір - від педкурсів до академії (1921-2016 рр.). Хмельницький : ХГПА.

Щербак, О. I. (2010). Професійно-педагогічна освіта: теорія i практика. Київ: Наук. світ.

\section{REFERENCES}

Dichkivska, I. M. (2004). Innovative Pedagogical Technologies. K iyv : Akademvidav.

Nichkalo, N. G. (Red.). (2002). State standards of vocational education: theory and methodology. Khmelnitsky: TUP.

Nichkalo, N. G., Filipchuk, N.O., Chemberzhi, M.I., Kharchenko, P.V. \& Nikolay, G.Y. Art in the development of personality. Chernivtsi : Zelena Bukovina.

Kremen, V. \& Tkachenko, V. (1999). Ukraine: The Path to Himself. Problems of social transformation. Kiyv.

Kremin, V. (2012). The spirituality and culture of society are determined by the development of education. Edukacja wspoteczens twachwielo kulturowych. Warszawa.

Kremin, V. G. Philosophy of the national idea. Man. Education.

Nichkalo, N.G. (2013). Professional training of the adult population: theoretical and methodological principles. Kiyv-Kirovograd: Imex.

Nichkalo, N.G. Theoretical and methodological problems of the development of research on pedagogy and psychology of vocational education. Materials 1 intern. fil.-cult. readings. Lviv.

Radkevich, V. O. (1999). Integration of the general artistic and professional training of specialists in the artistic profile. Pedagogics and psychology of vocational education. Lviv, 1, 68-72.

Radkevich, V. O. (2000). The concept of vocational education. Vocational and technical education, 2, 43-47.

Shorobura, I. M. (2016). Historical and pedagogical dimension - from the pedagogues to the academy (19212016). Khmelnitsky: KhGPA.

Shcherbak, O. I. (2010). Professionalpedagogical education: theory and practice. Kiyv : Science. world.

Стаття надійшла 16.10.2019 p. 